\title{
SINTESIS MEMBRAN NATA DE PINA DAN APLIKASINYA UNTUK ADSORPSI ZAT WARNA TEKSTIL REMAZOL RED RB
}

\author{
I N. Sukarta \\ Program Studi Kimia FMIPA Universitas Pendidikan Ganesha, Singaraja, Bali, Indonesia \\ Email: nyoman.sukarta@undiksha.ac.id
}

\begin{abstract}
ABSTRAK
Pada penelitian ini limbah kulit nanas dimanfaatkan menjadi membran nata de pina serta digunakan sebagai adsorben penyerap zat warna remazol red $R B$. Tujuan penelitian ini untuk mensintesis membran nata de pina, mengetahui $\mathrm{pH}$, konsentrasi dan waktu kontak optimum adsorpsi, pola isoterm, serta adsorpsi maksimum. Hasil penelitian menunjukkan bahwa membran selulosa nata de pina berhasil disintesis dan berpotensi menjadi adsorben dalam menjerap zat warna remazol red RB. Hasil FTIR menunjukkan bahwa membran nata de pina merupakan membran selulosa dengan hasil uji swelling sebesar 187,9\%. Kondisi optimum yaitu pada pH 2 dengan daya serap 17,12 mg/g, konsentrasi pada $80 \mathrm{mg} / \mathrm{L}$ dengan daya serap 22,36 $\mathrm{mg} / \mathrm{g}$ dan waktu kontak optimum adsorpsi pada 120 menit dengan daya serap 25,29 mg/g. Adsorpsi zat warna Remazol red $R B$ memenuhi pola isoterm adsorpsi Langmuir dengan daya adsorpsi maksimum sebesar 0,0219 $\mathrm{g} / \mathrm{g}$ atau $21,9 \mathrm{mg} / \mathrm{gadsorben}$.
\end{abstract}

Kata kunci: Nata de pina, adsorpsi, membran, Remazol red $R B$

\begin{abstract}
This study utilized pineapple peel waste into a membrane of nata de pina and used as an adsorbent for remazol red RB. The purpose of this study was to synthesis nata de pina membranes, determine the optimum $\mathrm{pH}$, concentration and contact time of adsorption, isotherm pattern, and the maximum adsorption. The results indicated that cellulose nata de pina membranes were successfully synthesized and had the potential to become adsorbents for absorbing remazol red RB dyes. FTIR results showed that membrane nata de pina was a cellulose based membrane with swelling test result of 187.9\%. The optimum conditions were at pH 2 with adsorption capacity of $17.12 \mathrm{mg} / \mathrm{g}$, concentration of $80 \mathrm{mg} / \mathrm{L}$ with absorption capacity of $22.36 \mathrm{mg} / \mathrm{g}$ and contact time at 120 minutes with absorption capacity of $25.29 \mathrm{mg} / \mathrm{g}$. The adsorption of remazol red RB dye has fulfilled the pattern of Langmuir adsorption isotherm with maximum adsorption of $0.0219 \mathrm{~g} / \mathrm{g}$ or $21.9 \mathrm{mg} / \mathrm{g}$ adsorbent.
\end{abstract}

Keywords: Adsorption, Nata de pina, membrane, Remazol red RB

\section{PENDAHULUAN}

Industri batik merupakan industri yang saat ini berkembang cukup pesat di Indonesia. Sejak pada tanggal 2 Oktober 2009 ditetapkan sebagai hari batik nasional omset pengusaha batik naik hingga 50\% (Aliyuddin \& Wesen, 2018). Berpijak pada data yang dimiliki oleh Kementrian Perindustrian, Sampai oktober 2017 telah tercatat, nilai produksi batik dan ekspor batik sudah mencapai USD 51,15 juta naik secara signifikan dari capaian semester I Tahun 2017 sebesar USD 39,4juta. Sejalan dengan pertambahan jumlah industri tekstil yang semakin meningkat, maka hasil sampingan yang diproduksi sebagai limbah juga semakin banyak. Hasil sampingan yang dihasilkan dari industri batik salah satunya adalah limbah cair zat warna sintetik. Limbah tersebut banyak yang dibuang di badan perairan seperti sungai dan bersifat nonbiodegradable, yang mana mikroorganisme tidak mampu untuk menguraikannya sehingga menjadi sangat berbahaya (Septiyani, dkk. 2017). Sekitar tujuh puluh persen lebih zat warna sintetik yang digunakan dalam industri tekstil merupakan zat warna yang termasuk dalam golongan azo seperti contohnya 
Remazol red RB (Suprihatin, 2014).

Dari dampak yang dapat ditimbulkan oleh limbah zat warna ini, maka perlu diadakan upaya pengolahan limbah cair batik agar polutan yang terkandung dapat berkurang dan lebih ramah lingkungan. Banyak penelitian yang sudah dilakukan dalam pengolahan limbah Remazol red RB. Salah satunya yaitu menggunakan metode adsorpsi. Adsorpsi merupakan metode yang sering digunakan karena sangat efektif, praktis dan ekonomis untuk menghilangkan kandungan polutan dalam limbah cair. Adsorpsi ini dapat dilakukan dengan menggunakan adsorben berupa membran. Saat ini pembuatan membran dari polimer alam telah banyak dikembangkan karena lebih ramah lingkungan dari pada polimer sintesis. Salah satu membran dari polimer alam yang dapat digunakan untuk mengadsorpsi limbah Remazol red $R B$ adalah membran selulosa dari Nata de pina. Nata de pina adalah jenis nata yang medium fermentasinya berasal dari ekstrak nanas yang difermentasi dengan bantuan bakteri Acetobacter xylinum (Hamad, 2017). Kulit nanas selama ini belum dimanfaatkan dan hanya dibuang menjadi sampah. Sehingga hal ini berdampak menimbulkan pencemaran lingkungan. Kulit nanas ini berpotensi untuk dimanfaatkan menjadi Nata de pina. Selulosa merupakan zat utama yang terkandung dalam Nata de pina.Nata de pina memiliki sifat penjerap yangkuat berupa selulosa bacterial.

Penelitian tentang pembuatan nata dari kulit nenas sudah banyak dilakukan. Aprilia (2009) melaporkan bahwa, Nata de pinayang dibuat dari kulit nenas dapat mengikat logam kobalt (II) sebesar 19,24\%. Rukhman (2012) berhasil membuat membran selulosa mikrobial dari nisbah filtrat kulit buah nanas. Oleh sebab itu, nata ini cocok digunakan sebagai bahan utama pembuatan membran selulosa yang dapat menjerap zat warna Remazol red RB. Maka dari itu dilakukanlah penelitian mengenai pemanfaatan kulit buah nanas sebagai membran nata de pina untuk menjerap zat warna tekstil Remazol red RB. Penelitian ini dapat menjadi temuan baru yang sangat bermanfaat. Selain itu, dapat mengurangi bahaya pencemaran zat warna Remazol red $R B$ dan secara tidak langsung juga dapat mengurangi pencemaran lingkungan oleh limbah kulitnanas.

\section{METODE PENELITIAN}

\section{Pembuatan Nata de pina}

Kulit nanas yang sudah dibersihkan ditambahkan dengan air perbandingan (1:4) yakni 200 gram kulit nanas ditambah dengan $800 \mathrm{~mL}$ air, lalu diblender kemudian disaring agar diperoleh filtratnya. Filtrat yang diperoleh selanjutnya ditambahkan sukrosa $7,5 \%(w / v)$ dan amonium sulfat $0,5 \%(w / v)$. Selanjutnya filtrat direbus pada suhu $100^{\circ} \mathrm{C}$ selama 15-20 menit. Filtrat ditampung dalam baki, ditutup dengan kertas steril hingga filtratnya dingin. $\mathrm{pH}$ fitrat selanjutnya diatur dengan penambahan asam asetat $2 \%(\mathrm{v} / \mathrm{v})$ sehingga pH-nya menjadi 4,5. Kemudian ditambahkan bakteri inokulum Acetobacter xylinum ke dalam baki sebanyak 10\%. Baki dibungkus dengan kertas steril dan dieratkan dengan tali. Media diinkubasi sampai 7 hari pada suhu kamar sampai nata terbentuk.

\section{Pemurnian Nata de pina}

Pada larutan natrium hidroksida dengan konsentrasi $1 \%$ (w/v) Nata de pina direndam selama 24 jam pada suhu kamar. Selanjutnya nata de pina dinetralkan dengan cara direndam selama 24 jam pada larutan asam asetat $1 \%$ (v/v). Untuk memurnikan nata digunakan natrium hidroksida dan asam asetat sebanyak \pm 1 Liter. Setelah itu, nata dicuci dengan air beberapa kali sampai $\mathrm{pH}$ nata nentral kemudian nata dikeringkan dalam oven pada suhu $40^{\circ} \mathrm{C}$ sampai menjadi lembaran membran selulosa nata de pina (Aprilia,2009).

\section{Uji Swelling}

Uji swelling dilaksanakan dengan menimbang massa membran sebelum dan setelah direndam dalam air. Untuk mendapatkan massa kering $\left(\mathrm{W}_{\mathrm{k}}\right)$ maka membran yang dikeringkan pada suhu kamar kurang lebih selama 24 jam kemudian ditimbang. Massa basah $\left(\mathrm{W}_{\mathrm{b}}\right)$ diperoleh dengan cara membran direndam selama 6 jam mengunakan air. (Fathural, 2017). Perhitungan uji swelling dengan menggunakan persamaan sebagai berikut.

$$
\% S=\frac{W_{b}-W_{k}}{W_{k}} \times 100 \%
$$




\section{Uji FTIR}

Nata yang berbentuk lembaran dipotong sehinga terbentuk lembarn nata dengan ukuran $2 \times 2 \mathrm{~cm}$ lalu nata dijepit dengan pinset. Kemudian nata diletakkan di dalam tempat sampel selanjutnya dimasukkan di dalam instrumen FTIR. Dengan menggunakan bilangan gelombang 450-4000 $\mathrm{cm}^{-1}$ selanjutnya lampu dinyalakan tepat mengenai contoh.

Penentuan pH, Konsentrasi dan Waktu Kontak Zat Warna Remazol red RB Optimum

Membran nata berukuran kurang lebih $4 \times 4 \mathrm{~cm}$ dengan massa yang sama, masingmasing dimasukkan kedalam zat warna remazol red $R B$ dengan konsentrasi $60 \mathrm{mg} / \mathrm{L}$ sebanyak 50 mLpada $\mathrm{pH}$ berturut-turut 1, 2, 4, 7, 9 dan 11 dengan cara menambahkan $\mathrm{HCl}$ kemudian digoyang dengan shaker selama 120 menit. Membran dipisahkan dari larutan zat warna lalu dikeringkan. Larutan zat warna yang tersisa diukur konsentrasinya dengan menggunakan spektrofotometer UV-Vis Singel Beem jenis Shimadzu UV mini-1240 pada panjang gelombang maksimum. $\mathrm{pH}$ yang menghasilkan daya serap adsorpsi optimum digunakan untuk menentukan konsentrasi optimum. Variasi waktu yang digunakan 60, 90, 120, 150 dan 180 menit. Hasil pH dan waktu kontak optimum yang diperoleh digunakan untuk menentukan konsentrasi optimum. Variasi konsentrasi adsorpsi remazol red $R B$ pada $\mathrm{pH}$ optimum dan waktu kontak optimum berturut-turut adalah 10, 30, 60, 80 dan $100 \mathrm{mg} / \mathrm{L}$.

\section{Analisis Data}

Data $\mathrm{pH}$, konsentrasi dan waktu kontak optimum didapat dari kurva hubungan daya serap remazol red $R B$ yang teradsorpsi dengan $\mathrm{pH}$, konsentrasi dan lama waktu kontak. Nilai $\mathrm{x} / \mathrm{m}$ dapat dihitung dengan persamaan sebagai berikut.

$$
x / m=\frac{(C o-\mathrm{Cst}) \times \mathrm{V}}{\mathrm{m}}
$$

Keterangan:

$$
\begin{array}{ll}
\mathrm{x} / \mathrm{m} & =\text { massa zat warna teradsorpsi } \\
\mathrm{Co} & =\text { konsentrasi awal zat warna } \\
\mathrm{Cst} & =\text { konsentrasi setimbang zat warna } \\
\mathrm{V} & =\text { Volume zat warna } \\
\mathrm{m} & =\text { massa membran }
\end{array}
$$

Data karakteristik pola isoterm adsorpsi zat warna remazol red $R B$ diperoleh dari data adsorpsi yang didapat dengan pengukuran diterapkan ke dalam persamaan linear isoterm adsorpsi Langmuir dan Freundlich. Untuk mengetahui pola isoterm adsorpsi Langmuir diuji dengan persamaan:

$$
\frac{C}{x / m}=\frac{1}{(x / m)_{\text {mak.k }}}+\frac{1}{(x / m)_{\text {mak }}} C \text {. }
$$

Untuk isoterm adsorpsi Freundlich digunakan persamaan:

$$
\log (x / m)=k+1 / n \log C
$$

Data adsorpsi yang didapat dari pola isoterm Langmuir dan Freundlich disajikan dalam bentuk kurva. Data daya adsorpsi maksimum zat warna remazol red $R B$ yang teradsorpsi akan didapatkan dari karakteristik adsorpsi yang diperoleh.

\section{HASIL DAN PEMBAHASAN}

\section{Sintesis membran nata de pina dari limbah kulit nanas}

Nata de pina dari limbah kulit nanas berhasil disintesis menggunakan stater bakteri Acetobacter xylinum dalam proses fermentasi. Nata de pina yang diperoleh, berhasil dibentuk menjadi membran selulosa bakterial (Gambar 1) dari proses perendaman nata de pina selama 24 jam menggunakan larutan natrium hidroksida $1 \%(\mathrm{w} / \mathrm{v})$ dan penetralan selama 24 jam mengunakan larutan asam asetat $1 \%(\mathrm{v} / \mathrm{v})$.

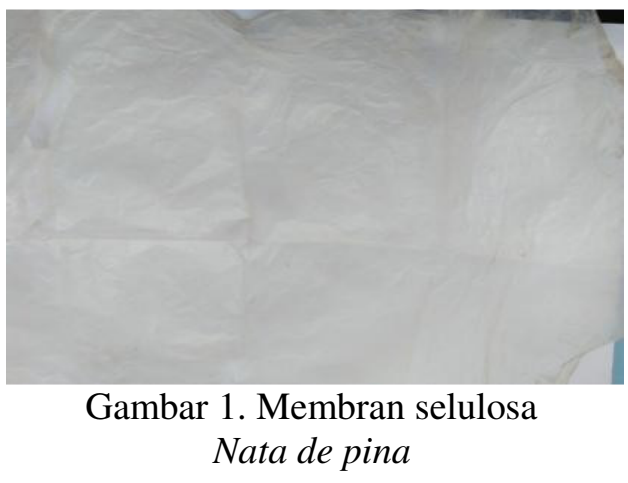

\section{Karakterisasi Membran Nata de pina Limbah Kulit Nanas}

Karakterisasi membran nata de pina diperoleh dari hasil uji ketahanan $\mathrm{pH}$, uji swelling dan uji FTIR. Berdasarkan hasil pengujian diperoleh hasil uji ketahanan $\mathrm{pH}$ 
bahwa membran selulosa dari nata de pina tahan pada $\mathrm{pH}$ asam, netral maupun basa. Hal ini dapat dilihat dari tetap utuhnya membrane walaupun direndam pada larutan asam, basa dan netral. Sementara itu, pada uji swelling diperoleh hasil sebesar 187,9\%. Dari analisis spektrofotometer Inframerah (IR) (Gambar 2) membran selulosa nata de pina menunjukkan adanya pembentukan membran selulosa yaitu terdeteksi pada bilangan gelombang $3425,58 \mathrm{~cm}^{-1}$ merupakan ulur gugus fungsi -OH. Sementara itu, vibrasi ulur dan tekuk dari keberadaan gugus C-H ditunjukkan dengan puncak pada bilangan gelombang 2900,94 $\mathrm{cm}^{-1}$ dan $1427,32 \mathrm{~cm}^{-1}$ serta diperkuat dengan adanya bilangan gelombang pada 1635,64 $\mathrm{cm}^{-1}$ yang merupakan gugus $\mathrm{C}=\mathrm{O}$. bilangan gelombang $1365,60 \mathrm{~cm}^{-1}$ menujukan gugus C-O ulur dan bilangan gelombang $1365,60 \mathrm{~cm}^{-1}$ mengindikasikan gugus fungsi -O-.

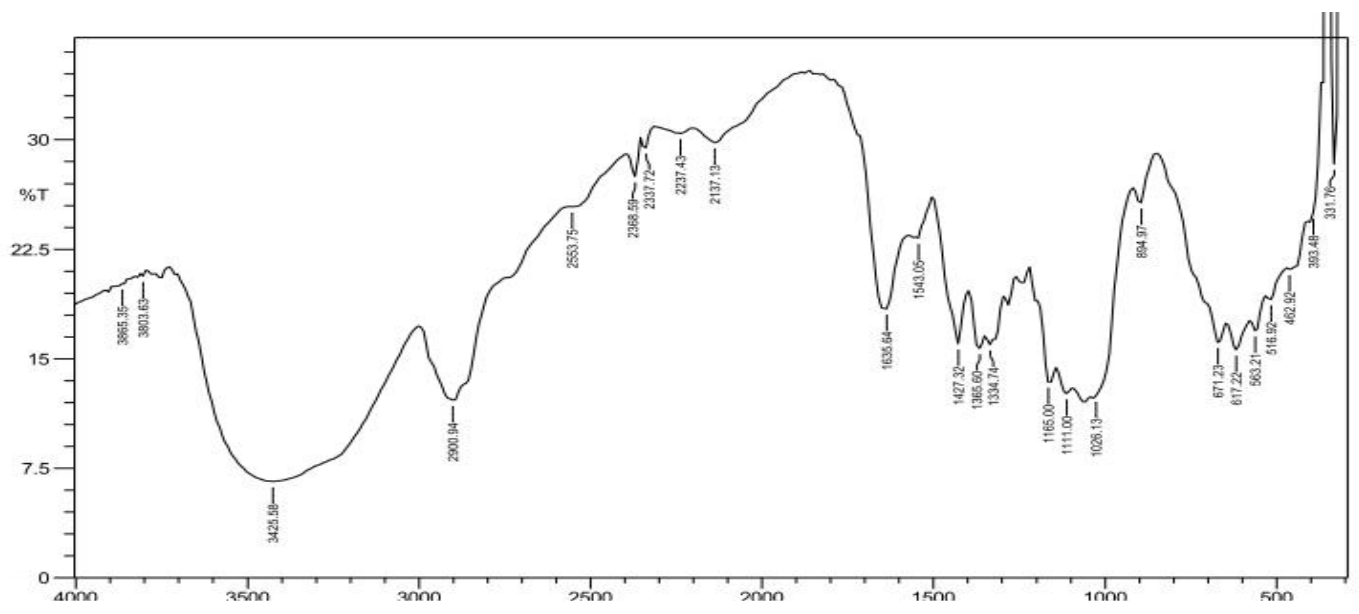

Gambar 2. Hasil uji gugus fungsi membran nata de pinadengan FTIR

pH, Konsentrasi dan Waktu Kontak Optimum zat warna Remazol red $R B$ yang dapat diadsorpsi oleh membran nata de pina

Zat warna remazol red $R B$ dapat teradsorpsi secara optimum pada sekitar $\mathrm{pH} 2$ dengan adsorpsi zat warna sebesar 17,12 $\mathrm{mg} / \mathrm{g}$. Kurva hubungan antara konsentrasi zat warna remazol red $R B$ yang teradsorpsi oleh membran selulosa nata de pina terhadap variasi $\mathrm{pH}$ dapat disajikan seperti pada Gambar 3.

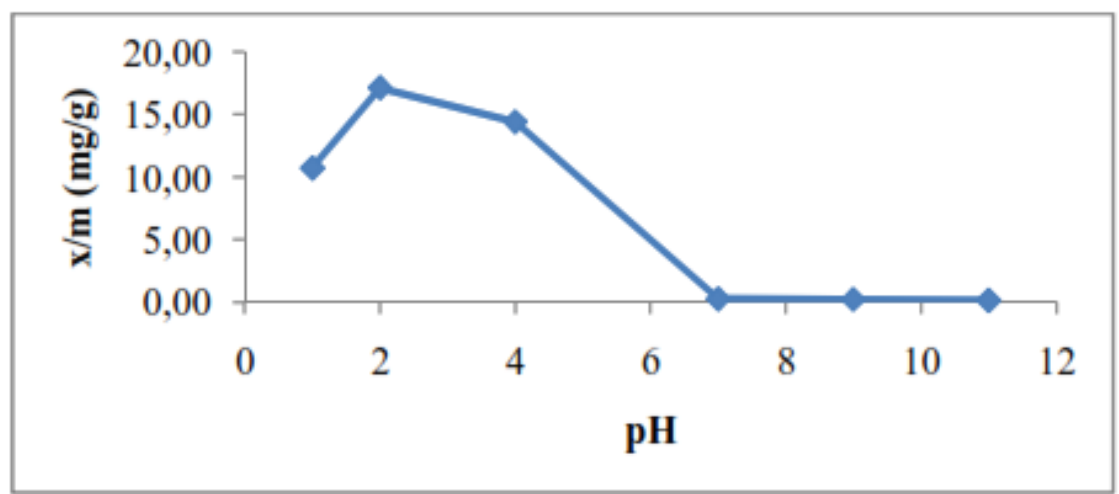

Gambar 3. Kurva hubungan antara daya serap zat warna remazol red $R B$ yang teradsorpsi oleh membran nata de pina terhadap variasi $\mathrm{pH}$.

Menurut Nasution (2015), perubahan distribusi muatan pada adsorben (nata de pina) dan zat warna remozol red RB sebagai akibat terjadinya reaksi baik protonasi maupun deprotonasi gugus-gugus fungsional yang disebabkan oleh adanya perubahan $\mathrm{pH}$ 
sistem. Pada pH 2 terjadi kenaikan adsorpsi hal ini dipengaruhi oleh ion $\mathrm{H}^{+}$pada remazol red $R B$. Zat warna awalnya dalam $\mathrm{pH}$ rendah (asam) akan terjadi deprotonasi (pelepasan $\mathrm{H}^{+}$) dan kemudian ketika membran selulosa nata de pina dimasukkan kedalam larutan zat warna, permukaan aktif selulosa akan mengalami protonasi (penambahan $\mathrm{H}^{+}$) terlebih dahulu, kemudian interaksi elektrostatik akan terjadi yang menyebabkan terjadinya perpindahan zat warna dalam larutan menuju ke permukaan selulosa nata de pina (adsorben) terprotonasi (Magfiroh, 2016). Berdasarkan $\mathrm{pH}$ optimum adsorpsi zat warna remazol red $R B$ yang di dapat, digunakan dalam penentuan konsentrasi optimum. Variasi konsentrasi yang digunakan yaitu $10-100 \mathrm{mg} / \mathrm{L}$. Kurva hubungan antara konsentrasi zat warna remazol red $R B$ yang teradsorpsi oleh membran nata de pina terhadap variasi konsentrasi dapat disajikan seperti pada Gambar 4.

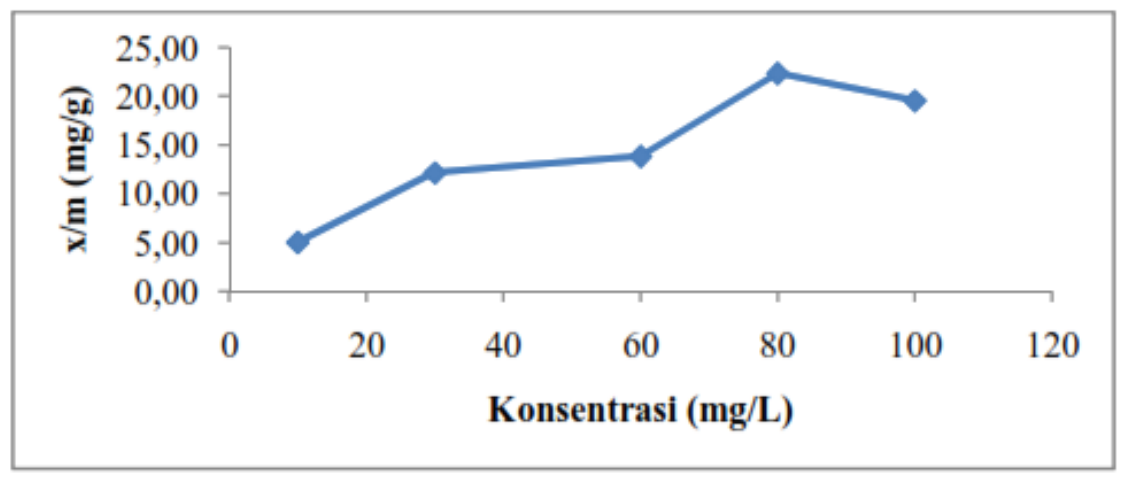

Gambar 4. Kurva hubungan antara daya serap zat warna remazol red $R B$ yang teradsorpsi oleh membran nata de pina terhadap berbagai variasi konsentrasi.

Pada Gambar 4 terlihat bahwa adsorpsi zat warna remazol red $R B$ meningkat dari konsentrasi $10 \mathrm{mg} / \mathrm{L}$ dan optimum pada konsentrasi $80 \mathrm{mg} / \mathrm{L}$, dengan daya serap sebesar 22,36 mg/g. Kemudian mengalami penurunan pada konsentrasi $100 \mathrm{mg} / \mathrm{L}$. Penurunan ini terjadi karena semakin besar konsentrasi zat warna remazol red $R B$ maka situs aktif pada selulosa yang dimiliki membran semakin jenuh. Adanya peningkatan konsentrasi menyebabkan, molekul zat warna cenderung membentuk agregat, sehingga difusi molekul zat warna dari larutan menuju permukaan adsorben terhambat (Yuanita, 2014). Hasil pH dan konsentrasi optimum digunakan dalam penentuan waktu kontak optimum. Degradasi optimum zat warna remazol red $R B$ berlangsung pada waktu kontak 120 menit, dengan adsorpsi zat warna sebesar 25,29 $\mathrm{mg} / \mathrm{g}$. Pada menit 150 adsorpsi mengalami penurunan. Hal ini dikarenakan situs aktif pada membran mengalami kejenuhan. Semakin lama waktu kontak maka kemungkinan proses adsorpsi juga semakin meningkat, tetapi ketika kondisi setimbang telah tercapai adsorben cenderung melepas (desorpsi) zat warna sehingga persentase adsorpsi menjadi berkurang, ini menandakan membran selulosa nata de pina mengalami waktu jenuh (Nasution, 2015). Kurva hubungan antara konsentrasi zat warna remazol red $R B$ yang teradsorpsi oleh membran selulosa nata de pina terhadap waktu kontak dapat disajikan seperti pada Gambar 5. 


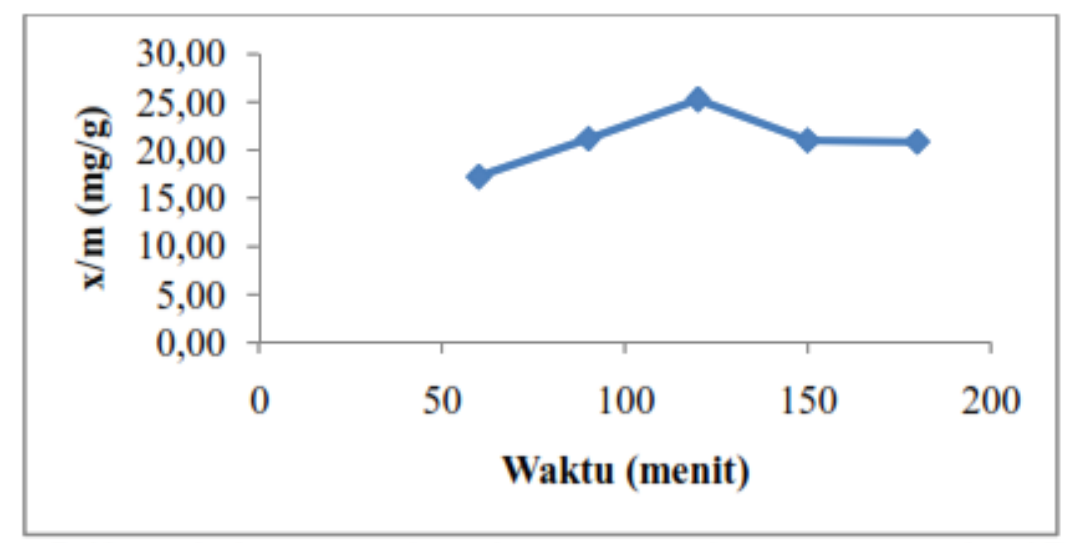

Gambar 5. Kurva hubungan antara daya serap zat warna remazol red $R B$ yang teradsorpsi oleh membran nata de pina terhadap berbagai waktu kontak.

\section{Pola isoterm adsorpsi zat warna Remazol red $R B$}

Daya adsorpsi maksimum zat warna remazol red $R B$ oleh membran selulosa nata de pina ditentukan dengan menggunakan persamaan adsorpsi Langmuir dan Freundlich. Dari data konsentrasi zat warna remazol red $R B$ yang teradsorpsi oleh membran selulosa dapat dibuat kurva hubungan antara konsentrasi zat warna setimbang $(\mathrm{C})$ terhadap konsenrasi zat warna setimbang dibagi massa zat warna teradsorpsi $(\mathrm{C} /(\mathrm{x} / \mathrm{m}))$ dan kurva hubungan antara $\log$ konsentrasi zat warna setimbang ( $\log \mathrm{C}$ ) terhadap log massa zat warna teradsorpsi (log $\mathrm{x} / \mathrm{m})$. Kurva hubungan antara konsentrasi zat warna setimbang $(\mathrm{C})$ terhadap konsentrasi zat warna setimbang per massa zat warna teradsorpsi $(\mathrm{C} /(\mathrm{x} / \mathrm{m}))$ disajikan pada Gambar
4 dan kurva hubungan antara $\log \mathrm{C}$ terhadap $\log \mathrm{x} / \mathrm{m}$ disajikan pada Gambar 5. Daya adsorpsi maksimum zat warna remazol red $R B$ oleh membran selulosa nata de pina diperoleh dari persamaan isoterm adsorpsi Langmuir. Diperoleh persamaan garis lurus isoterm adsorpsi Langmuir $\mathrm{y}=45,62 \mathrm{x}+$ 516,5 yang memiliki slope $(\text { gradien })^{1} /\left(\frac{x}{m}\right)_{\text {maks }}=45,62$. Maka nilai $\left(\frac{x}{m}\right)_{\text {maks }}$ diperoleh sebesar $0,0219 \mathrm{~g} / \mathrm{g}$ atau $21,9 \mathrm{mg} / \mathrm{g}$ dengan nilai $\mathrm{R}^{2}=0,952$. Hal ini menunjukkan daya adsorpsi maksimum zat warna remazol red $R B$ menggunakan membran selulosa nata de pina sebesar 21,9 $\mathrm{mg} / \mathrm{g}$.

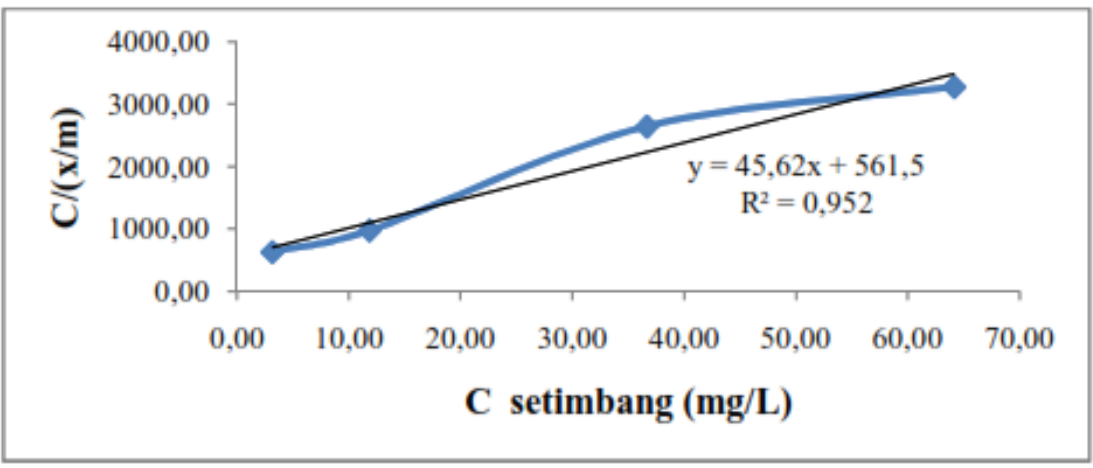

Gambar 6. Kurva Hubungan Antara Konsentrasi Setimbang (C) Terhadap C/(x/m) 


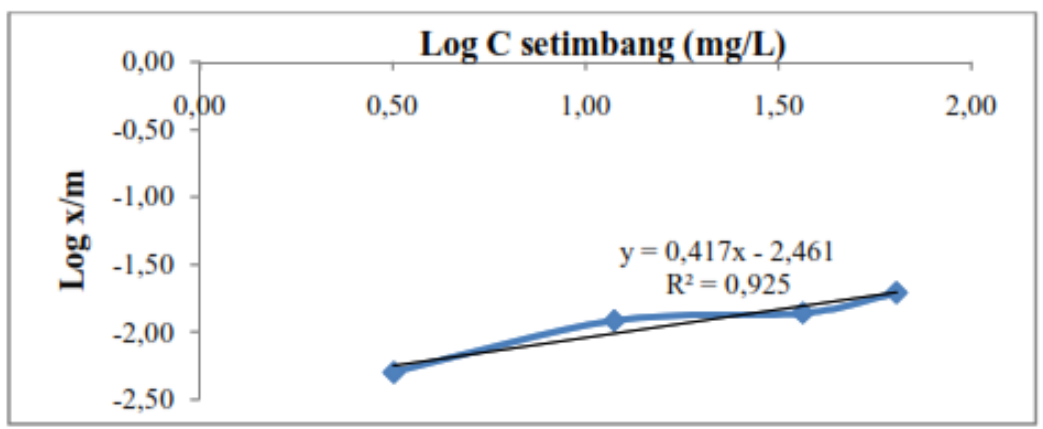

Gambar 7. Kurva Hubungan antara $\log C$ terhadap $\log \mathrm{x} / \mathrm{m}$

Dari nilai $\mathrm{R}^{2}$ yang diperoleh, maka dapat dikatakan adsorpsi zat warna remazol red $R B$ oleh membran mengikuti pola isoterm Langmuir dan tidak mengikuti pola isoterm Freundlich. Oleh karena itu, adsorpsi zat warna remazol red $R B$ oleh adsorben membran dapat dikatakan terjadi pada lapisan monolayer baik secara fisik melalui pori-pori yang ada pada sisi permukaan adsorben, atau secara kimia melalui interaksi gugus hidroksi $(-\mathrm{OH})$ yang ada pada selulosa dengan sisi aktif dari adsorbat (Crisyanti, 2018).

\section{SIMPULAN}

Sintesis membran nata de pina dari limbah kulit nanas berhasil dibuat dengan karakterisasi hasil uji swelling membran yang diperoleh sebesar 187,9\%, dan hasil uji FTIR terdeteksi pada bilangan gelombang 3425,58 $\mathrm{cm}^{-1}$ yang menunjukkan adanya gugus fungsi -OH ulur, munculnya bilangan gelombang $2900,94 \mathrm{~cm}^{-1}$ dan 1427,32 $\mathrm{cm}^{-1}$ mengindikasikan adanya gugus $\mathrm{C}-\mathrm{H}$ dengan vibrasi ulur dan tekuk. Adanya gugus $\mathrm{C}=\mathrm{O}$ ditunjukan oleh adanya bilangan gelombang $1635,64 \mathrm{~cm}^{-1}$, Bilangan gelombang 1111,00 $\mathrm{cm}^{-1}$ menunjukkan adanya gugus $\mathrm{C}-\mathrm{O}$ ulur dan bilangan gelombang $1365,60 \quad \mathrm{~cm}^{-1}$ mengidikasikan adanya gugus -O-. Adsorpsi zat warna Remazol red $R B$ optimum oleh membran nata de pina terjadi pada kondisi $\mathrm{pH}$ 2 dengan daya serap sebanyak $17,12 \mathrm{mg} / \mathrm{g}$, konsentrasi optimum pada $80 \mathrm{mg} / \mathrm{L}$ dengan daya serap sebanyak $22,36 \mathrm{mg} / \mathrm{g}$ dan waktu kontak optimum pada 120 menit degan daya serap sebanyak 25,29 $\mathrm{mg} / \mathrm{L}$. Pola isoterm adsorpsi Remazol red $R B$ oleh membran selulosa nata de pina memenuhi pola isoterm Langmuir. Kapasitas adsorpsi maksimum sebesar 0,0219 g/g atau 21,9 mg/g.

\section{DAFTAR PUSTAKA}

Aliyuddin, A., dan Wesen, P. 2018. Pengolahan Air Buangan Industri Batik Menggunakan Bioreaktor Hibrid Bermedia Bioball. Jurnal Ilmiah Teknik Lingkungan, 8(2): 7887.

Aprilia, L. 2009. Preparasi Produk Nata de pina Dan Aplikasi Pengikatannya Terhadap Logam Kobalt(II). Institut Pertanian Bogor.

Chrisyanti, Desriana, dkk. 2018. Blue Methylene Retrieval Using SilicaSalicylic Acid Modified Filtering. Journal of Scientific and Applied Chemistry, 21(1):19-23.

Fathural, Baani, dkk. 2017. Pengaruh Agen Pencangkok Heparin Terhadap Kemampuan Transpor Kreatinin Dan Urea Membran Turunan Kitosan. Jurnal Kimia Sains dan Aplikasi, 20(2): 92 -94.

Hamad, Alwani, dkk. Potensi Kulit Nanas Sebagai Substrat dalam Pembuatan Nata de pina. Jurnal Riset Sains dan Teknologi, 1(1): 9-14.

Kementerian Perindustrian. 2017. Hingga Oktober 2017, Nilai Ekspor Batik Lampaui USD 51 Juta. Dalam http://www.kemenperin.go.id/artikel /18591/Hingga-Oktober2017,-NilaiEkspor-BatikLampaui-USD-51-Juta. Diakses pada tanggal 1 Desember 2018.

Maghfiroh, Lailatul, dkk. 2016. Pengaruh pH Terhadap Penurunan Zat Warna Remazol Yellow FG oleh Adsorben Selulosa Bakterial Nata De Coco. Jurnal Sains dan Seni ITS, 5(2):23373520. 
Nasution, Hasmalina, dkk. 2015. Penentuan Waktu Kontak Dan pH Optimum Penyerapan Zat Warna Direct Yellow Menggunakan Abu Terbang ((Fly Ash) Batubara. Universitas Tanjungpura, Pontianak, 747-756.

Rukhmana, Arie Megha. 2012. Membran Selulosa Berbahan Dasar Kulit Buah Nanas Sebagai Adsorben Zat Warna Tekstil Biru Metilena. Departemen Kimia, Institut Pertanian Bogor.

Septiyani, Elda, dkk. 2017. Penyisihan Kandungan Sulfida Dan Warna Dalam Limbah Industri Batik
Berbahan Pewarna Dasar Remazol red RB.C.I. Reactive Red 198 Menggunakan Teknologi Membran Nanofiltrasi. Jurnal Teknik Lingkungan. 6(1).

Suprihatin, H. 2014. Kandungan Organik Limbah Cair Industri Batik Jetis Sidoarjo dan Alternatif Pengolahannya. Jurnal Kajian Lingkungan. 2(2): 130-138.

Yuanita, Dewi. 2014. Penggunaan Lumpur Aktif Sebagai Material Untuk Biosorpsi Pewarna Remazol. Jurnal Molekul, 9(2): 93-100. 